\title{
State Initiatives in Conflict Resolution as tool of Development: A Case of the Northeast India
}

\author{
By: Md. Ashrafuzzaman \\ Assistant professor, Department of Anthroology,University of Chittagong, Bangladesh.Mailing Address: \\ 994/A East Nasirabad, 2 No Gate Moshjid Goli, The Priencess,B2,G.P.O. Box: 1076,Chittagong: \\ 4000.Cell:008801819612460
}

Email: frankashru@gmail.com or dvs13mas@student.lu.se

\begin{abstract}
This paper focuses on the relations between state initiatives in conflict resolution as a tool of bringing development in northeast India. The main task of this paper is to find out the historical importance of the role of state as an actor behind developmental activities in developing countries like India. I will discuss ethnic conflicts of the Northeast India and will also show what steps have been taken by Indian central Government to resolve the issue. I will also describe how and for what extent ethno-political conflicts started in this region with the historical background of ethnopolitical conflicts in institutional context. This paper will show how ethnic movements have been continuing and what measures have been taken by the government to solve the ethnic conflicts in different states of India, particularly in the Northeast area as well as focus on different cleavages and ethnic conflicts within the state. The impact of colonialism on the Northeast India is focused here emphasizing on the precondition and historical legacy of colonialism. There is a brief discussion on some provisions of law in this paper and constitutional provisions which were created in colonial India, but still exist in the Indian states. Internal conflicts is the main focus point of the paper paying attention to national and state-building strategies, in which I will further show how they act as external factors of development.
\end{abstract}

Key Words: State Initiatives; North-East India; Conflict Resolution; internal of development; external of development; Peace-building

\section{Introduction}

The Northeastern parts of India are the home of different ethnic and linguistic distinct people who are called tribes. The Northeast region is quite far from the heart of India. The ethnicity of the Northeast is premise of ethnic conflict. Roy suggests the notion of 'Nation from below' to form an ethnic line of one name, common heritage, common language, common culture and a common identity for all. Identity countering other results in democratic movements, anti-state armed struggles, ethnic cleansing and other similar actions (Roy, 2005:2177).However Peace and political stability are the precondition of sustained development. Because development is not something that takes place over night but it takes time and needs peaceful atmosphere. Therefore, it has been observed that conflict-torn area and unstable political arena experience lessdevelopment over the years. The Northeast India is such a case of relationship between conflict and underdevelopment. Indian state has taken different conflict resolution strategies to ensure sustained development in the Northeast India for the last couple of decades, but most of these appeared unproductive. The Northeast India has experienced ethnic tensions and violence since independence from British rule in 1947(Gwswami.2013:28). The ethno-nationalist movements 
were created soon after declaring the seven (now eight) states. The state that the leaders of sovereign India inherited was a product of both colonial initiatives and pressures from the national movement against colonialism. The British in India created the basic state architecture, including centralizing territorial control, a modern army and civil service, rule of law, and the beginning of constitutional democracy (Kohli, 2004:255). But these characteristics were limited spatially. The Northeast India which has always been hard to control by the State because of geographical specificity and location still stayed limited in its economic scope and its downward reach into society. Indian government allocate special facilities for the conflicting states not for their ethnic strife only or not for extreme radicalism, but it is done for the overall development of whole India. But the question rises whether the North-East India will get advanced for its special category or not.

\section{Conflicts and Development: A Conceptual Framework}

Appropriate strategy of any country for development depends not only on internal basis but also on its external conditions. Internal and external agencies are considered significant for both conflict resolution and development which could be regarded as a general theoretical framework in order to find out the intervention of the state in greater development of the Northeast India. For better understanding of the issue, I like to mention here that economy, politics and society are considered as the internal basis of development; on the other hand government policies and national views of the state are considered as external conditions. The idea of the external and internal of development has high relevance for the development strategies and debates in present world since recently development has become a discourse of interdependence, particularly for developing countries and for postcolonial states, which have been struggling to get rid of a perennial state of underdevelopment. After the independence of India, state took the responsibility of national development in the Northeast India to bridge the external and internal of development because it was supposed that the 'mind' of the state could be exercised to direct the external 'body' (Cowen and Shenton,1996:338). Rostow suggested that "the one stage can be "constructed" out of the other although in reality he recognizes that in contemporary societies the change comes about as a result of external circumstances" (Rist ,1999:96). According to Deborin, "Between the external and internal world there exists a certain distinction, and at the same time a definite similarity, so that we arrive at the cognition of the external world through impressions, but they are impressions produced by objects of the external world"(Cowen and Shenton 1996:80).According to Mao: "external causes are the condition of change and internal causes are the basis of change, and that external causes become operative through internal causes... in order to understand the development of a thing we should study it internally and its relations with other things" (cited by Cowen and Shenton,1996:78). Arrighi says: "the analysis of internal class structure may not be subordinated to the external domination of a colonial and neocolonial structure. In a suitable temperature an egg changes into a chicken, but no temperature can change a stone into a chicken, because each has a different basis" (Cowen and Shenton, 1996:74). At the same way, internal and external have their own traits and importance. In this paper, society is considered as an internal cause which is the base of all development, and state is the agency which accelerates the developmental process of a country affecting different internal situations. When the internal of development acts as the external condition of the state, the external factor of state development becomes the agency of aid and support, not in case of 
financial issues only; and therefore the paper discusses that the nature and the role of the state play the most important part behind the development. This conceptual and theoretical framework will be contextualized with the specific reference to the Northeast India where the main focus points are nature and history of ethnic conflicts and these are very important as external factors of development. Then, a deep analysis of the policies to resolve ethnic conflicts adopted by the state for development is made, and it is shown how they act as the external factors of development. To understand the state policy deeply, we should consider the legacy by British government but inherited by Indian States as part of colonial India, lately sovereign India.

\section{Ethnic conflicts and the state of development as internal's of development in the Northeast India}

Ethnic violence is high in the Northeast India constituting the eight states of Assam, Arunachal Pradesh, Manipur, Meghalaya, Mizoram, Nagaland Tripura and Sikkim . Dev's account of 75 major ethnic groups and sub-groups who speak about 400 languages and for this India is projected as a real multi-ethnic society. In Arunachal , Manipur, Meghalaya, Mizoram, and Nagaland, various tribes comprise more than $60 \%$ of the population while Assam alone has 23 diverse tribes (Dev 2004:47-49). A huge and various nontribal inhabitants intense mostly in Assam, Manipur, and Tripura. During the British colonial rule, these three regions were included in the mainstream India. But later the British colonial authority drew separate borders in this territory for what there created an ethnic diversity (Barua,S.2007:16-17).The main aim of marking these draw lines was to ensure security of the areas from external powers. But many ethnic groups were created because of the political boundaries made by the British Empire. Such division or disunity prevailed even after the independence of India. Before the British colonial rule, people of the hills and the plains were interrelated but British rule divided them. People were grossly mistreated, discriminated against and ruled by outsiders. As a result, the process of development in the hills and Northeast areas had a great impact on the nationalist movement and independence (Borah, R.2011:23).

The entire development process is affected by three main regional dynamics: (i) national security and the deploying military in the region, (ii) the construction of the Northeast and its peoples in other parts of India, and (iii) the settlement of 'outsiders' in the Northeast. The three contestations are linked with each other and constitutive of social, political, and economic relations(Bhaumik 2007;Hazarika 1995 cited by Mcduie-Ra, D.,2008:190-194). Despite local variations, they are predominant in this region which is dominated by national security and militarization. The Northeast regions shares its 90 percent borders with other countries of which China and East Pakistan (now Bangladesh) hold much attention because India fought wars with them since Independence. So, the Government of India is always cautious of ensuring national security in this region. Therefore, the geographical location of the region regarding development has a great impact in the process of state-building in South Asia although several separatist groups are creating insurgency in the Northeast region since Independence(ibid).

Kohli,A. ("Can Democracies Accommodate Ethnic Nationalism?"1997:342-343) wrote that ethnic movements can operate in a well-institutionalized state peacefully if the state is able to set boundaries within. Dasgupta says that such granting of autonomy inspired other tribal people who remained silent by this time (Dasgupta, 1997:368). Though some groups were satisfied with autonomy, the movements for autonomy continued with the demand of independence 
(Dasgupta,1997: 367). The strategy of establishing autonomy could not remove unrest and insurgency increased through the process of ethnic accommodation as other means of solution became inactive in case of insurgency in this region (Baruah,S.1999:106-114). Competition over political power, socio-economic disparities between groups, historical tensions between minorities and majorities or border location of minority communities or their kin groups in neighboring states became the cause of ethnic conflicts in India. Brubaker and Laitin (1998:424425 ) found ethnicization the main reason of rising ethnic violence. The Northeast region fell in great dilemma for its multicultural traditional, described a great feature of India. Different ethnic groups' demanding national identity brought about wide spread ethno nationalism. When India was trying to establish a unique self-identity based on religion and culture, movements for national-identity sprout in different parts of India.

\section{Conflict Management and Peace-building Strategies in the Northeast India}

Suggesting a secure environment first, the armed forces prescribed to activate powerful government institutions without any interference because national power is necessary to resist the ongoing conflicts in this region. Empowerment of civil authority is also suggested but such interference of military and civil government for implementing peace against violence is not welcomed(Lacina, B. 2007:175-176). This doctrine of Indian military, grounded on the survival of insurgency, reflects the counterinsurgency and unconventional warfare in India and represents the existence rebel groups (ibid). Though civilians do not support rebels always, they can influence the government force or help the existence of the rebels .

Delhi's initiatives to establish a good relation in the Northeast India between the civilians and the security forces are praiseworthy as it has reduced the violence to a great extent since 1989. Though the steps were criticized bitterly by the human rights organizations, the government succeeded to ensure civilians' security, except some unwanted incidents(Lacina,B.2007:177179). As the separatist became notorious for brutality and crime, the government reached their political goal easily despite some coercive responses because of political initiatives. Existing inner line, the subdivision of Assam, the recognition of new tribes, and reformation on immigration were criticized severely. The government invested huge money for overall development of the region but ordinary citizens were dissatisfied which proved that there was corruption or lack of proper policy. The distance between warfare doctrine and nature of violence might be another reason and separatist were more benefited from the gap between rule of law and exploiting politics. Delhi tried to ensure security through negotiation and a generous amount of development along with accommodating the rebels but violence was not removed fully(ibid). Yet, policy and negotiation is continuous for implementing the rule of law in the Northeast India for peace.

\section{An Evaluation of the State and its Policy as an External of Development}

The British left their ideology and concepts of central territorial control, modern army and civil service, rule of law, and the beginning of constitutional democracy in India (Kohli, 2004:255) although the characteristics were limited. It was hard for the state to control the Northeast India 
because of its geographical specificity and location, and for its downward reach the region stayed limited economically. Many authors analysed the Indian state (i.e. Sanjib, B,2003; Kohli, A,2004: 221-243;Potter, Robert B. et al.,2004:72-73) and found that the colonial state's unwillingness to finance money and resources for setting up a formal land market, or there was no satisfactory government initiatives to ensure property right for the sake of preventing those conflicts. After 1947, the State chose some strategies regarding territorial control to solve the ethnic conflicts and put an end of arm rebellions in Northeast and these strategies created the ways of further development on the Northeast of India. But the State's initiatives to protect indigenous tribal restricting their rights to land ownership and exchange, business and trade licenses and access to elected office raised the notion of exclusive homelands, since certain ethnically defined groups were privileged, and ethnic conflicts increased because of such internal displacement in the region.

The countries surrounding Northeast India play vital role as external factors since some militant groups of China, Bangladesh and Burma share the Naga identity and there is mutual exchange of moral and material assistance among them. As a result, they can easily receive arms, guerrilla training and ideological schooling from others. But, the 'Congress System' contains the main principle of the 'Grand Coalition' about what Rajni Kothari (1964), the creator of the term, described, "consensus system which operates through the institution of a party of consensus"(Kothari 1989:51). The Congress party is mainly characterised by adherence to secularism and encompasses all the major sections and interests of society(Kothari 1989:27). From 1947 to 1967 Indian system was dominated by The Indian National Congress (INC). Later their position became stronger but at the state level they had to face more competition and subsequently became weaker. Wilkinson (2010) suggested both formal policies and particular action to evaluation the state approach toward insurgency in the Northeast. Indian government took praise worthy initiatives to pacify the turmoil states specially Mizoram. Allowing insurgent leaders to occupy highest positions in the states, making immigration easy for minority, consent to create new states, and providing local rule to the minority are the most effective steps taken by New Delhi. The government also provided adequate funds for accelerating development through improving infrastructure and living standards. The process of being part of India of the insurgent states were accelerated. Central government provided incentive for overall development of the states. The opportunities were gladly accepted by Mizo, Naga and the Manipuri people and the local leaders were much successful in election which gave them a chance to participate in the local politics to strengthen the process of autonomous state. At the same time a class of new local bureaucrats were created and they supported peace and stability while there were opposition powers who meant to defeat them politically.

The constitutional amendment of the Armed Forces (Special Powers) Act (AFSPA) in 1958 had an important effect on the formulation of policy as the process of transformation of power was in the hand of army and paramilitary and the same thing happened in case of self-determination in Northeast India in spite of India's different approaches (Hanjabam 2008:164). When states failed to realize the complexities of insurgencies, the AFSPA was applied but insurgency increased because of the massive use of force in the 1950s and the 1960s, and future negotiations became difficult. The insurgent groups received much sympathy from the local and the occupying force adopted conflict management and resolution mechanisms (Gwswami 2013:43). Through the three wars with Pakistan and Kashmiri militants, India proved it clearly that she is not willing to part any of her part. All 24MPs of the Northeast demanded cancellation of AFSPA but they 
could not persuade the 543 members of Lok Sabha in favour of them(Hanjabam,2008:163). The government's initiative regarding devolution of powers, increased spending on development, and measures to protect the minorities' culture and customs have them more reliable to the locals as well as to the insurgents. And for it, the leaders of the ethno nationalist movements realized that no more they could hold faith of the local, and their support. Though many fragmentations were created in Naga, the level of violence reduced to a great extent. Since a solution for putting an end to these conflicts had not been provided by direct state efforts (regarding to marginalized communities) it was not surprising that self-help appeared in a form of creating arm rebellions which had different goals including political autonomy. It is also important to notice that not all armed groups were rebels. Some of them came into being with the aim to combat insurgency. However, not every rebel organization was an ethnic militia (though they were mobilized along ethnic lines). For case in point, the United Liberation front of Assam (ULFA), created in the late of 70s, and a number of rebel groups in Manipur reared an aim to build a multi-ethnic support base. In fact, active state intervention became compulsory to protect discrimination regime since ethno-political conflicts became more complex and it turned into arm rebellions against the regime since ethnic violence and displacement deepened after the policy adopted by the state (Gwswami,2013:30-46). Mahandra Lama observes the nature of the problem in this region and describes that "political sensitivities" prevent the government from releasing data on displacement and (Lama, M., 2000 :26). All development projects regarding to Northeast India had been designed by the central government far away from the region and "all the energies and resources of the state went to the sustenance of that structure, leaving very little resources for other activities including development" in the region (Sanjib Barua, 2003:47).

\section{Conclusion}

At the end of the paper, I will return back to my beginning argument that peace and stability are two inescapable conditions for real, long-term and sustained development. Post-colonial India inherited different development apparatus, even the modern army, and used them in national and state-building in independent India. Society responded to every initiative of the state and created new conditions for entire development of the region. But, despite many initiatives and strategies taken by the Indian central states, the Northeast India is still in the paradox of peace and conflict and therefore effective and significant development is still far off the region. With the critical assessment of central policies and local positions, it is suggested that law and order shall be restored if all kinds of ethnic violence are reduced through ethnic reconciliation. If the existing turmoil situation is calmed, government will have much efforts and power to empower the local government agencies for the overall development of the Northeast India because in that case government will not remain busy in facing the militants and insurgency. At the same time, if the militants are appeased, local civilians will have faith on government regarding their security. Society and communities will be able to carry out programmes effectively for development in this region. In fact, participation and involvement of mass people should be incorporated in all sorts of development planning so that people can realize the local and regional stability is prerequisite for their own development which could weaken the support base of the militants in the Northeast India. Most important aspect of all policies of conflict resolution is people's trust and faith on the central government so that people can own the state policy as the safeguard of their lives and the essential pillar of their development in the Northeast India. 


\section{References}

[1] Armed Forces (Special Powers) Act, 1958 (with 1972 and 1986 amendments). Online available at: (http://mha.nic.in/pdfs/armed_forces_special_powers_act1958.pdf), accessed on 28February 2014.

[2] Brubaker, R. \& Laitin, D. D.,1998. Ethnic and Nationalist Violence. In The Annual Review of Sociology, Vol. 24, p.423-452,Online available at: R Brubaker, D Laitin Annual Review of sociology, 1998 - works.bepress.com, accessed on 2nd March 2014.

[3] Baruah, S., 2003. Citizens and denizens: ethnicity, homelands, and the crisis of displacement in northeast India. Journal of Refugee Studies, 16(1), pp.44-65,online available at: Lund University Library.

[4] Baruah, S.,2007. Post frontier Blues: Toward a New Policy Framework for Northeast India. In Policy Studies33, Washington: East-West Center. Online available at:

www.eastwestcenter.org/download/3252/32179/PS033.pdf, Online available at: 5th March 2014.

[5] Baruah, S.,1999. India Against Itself. Assam and the Politics of Nationality. Philadelphia: University of Pennsylvania Press.

[6] Borah, R., 2011. Role of civil society groups in promoting conflict resolution in India's Northeast, Paper prepared for the World International Studies Conference, Porto, Portugal, 17-20 August, 2011, Online available at:

www.academia.edu/947698/ROLE_OF_CIVIL_SOCIETY_GROUPS_IN_PROMOTING, accessed on,28 February 2014.

[7] Cowen, Michael P. and Shenton, Robert W., 1996. Doctrines of Development. Routledge, London.

[8] Dasgupta, J., 1997. Community, Authenticity, and Autonomy: Insurgency and Institutional Development in India's Northeast. The Journal of Asian Studies ,Volume 56, Issue 02, p.345-370, Online available at: Lund University Library.

[9] Dev, R., 2004. Human rights, relativism and minorities in North-East India, Economic and Political Weekly, Vol. 39, Issue No.43, p. 4747-4752.

[10] Escobar, A. (2011). Encountering Development: The Making and Unmaking of the Third World (New in Paper). Princeton University Press

[11] Goswami, N.,2013. Escalation and de-escalation of violence in insurgencies: Insights from Northeast India. In Small Wars \& Insurgencies, Vol. 24, No. 1, 28-56. Online available at: Lund University Libraries at 6 March 2014. 
[12] Hanjabam, S. S.,2008. The Meitei Upsurge in Manipur. In Asia Europe Journal, Vol. 6, No. 1, 157-159,Springer Online available at: link.springer.com/article/10.1007\%2Fs10308-007-0167-6 ,accessed on 5March 2014.

[13] Kohli, A., 2004. State-directed Development: Political power and Industrialization in the global periphery. Cambridge: Cambridge University Press.

[14] Kohli, A.,1997 . Can Democracies Accommodate Ethnic Nationalism? Rise and Decline of Self-Determination Movements in India. The Journal of Asian Studies, 56(2):325344,Online available at: Lund University Libraries.

[15] Kothari, R.,1964. The Congress System in India. In Asian Survey,vol.4.No.12.December 1964. Cambridge University press, Online available at: www.sp.units.it/.../South\%20Asian\%20Politics\%202012.../Kothari_Cong, 27 Feb,2014.

[16] Kothari, R.,1989. Politics and the People: In Search of a Humane India. Delhi: Ajanta.

[17] Lacina. Bethany.,2007. Does Counterinsurgency Theory Apply in Northeast India? India Review, vol. 6, no. 3, p.165-183, Routledge ,Online available at: Lund University Libraries, 27 February 2014.

[18] Lama, M.P., 2000. Internal displacement in India: causes, protection and dilemmas. Forced Migration, Online available at: www.popline.org/node/235380,accessed on,27 February 2014.

[19] Mcduie-Ra, D., 2008. Between National Security and Ethno-nationalism: The Regional Politics of Development in Northeast India, Journal of South Asian Development , 3:2 ,p.185-210,SAGE Publications Los Angeles/London/New Delhi/Singapore,Online available at:

http://sad.sagepub.com/content/3/2/185, accessed on 2nd March 2014.

[20] Potter, Robert B. et al., 2004. Geographies of Development. Harlow: Prentice Hall, Enland.

[21] Rist, Gilbert., 2008. The History of Development: from Western Origins to Global Faith, 3rd edition, London: Zed Books.

[22] Vandekerckhove, Nel.,2009.“WE ARE SONS OF THIS SOIL”The Endless Battle over Indigenous Homelands in Assam, India, Critical Asian Studies 41:4 (2009), 523-548, Routledge.

[23] Wilkinson, S. I.,2010. India, Consociational Theory, and Ethnic Violence. In Baruah, S. (ed.) Ethnonationalism in India: A Reader. New Delhi: Oxford University Press, pp. 431 457. 